\title{
中国雲南省西双版納夕イ族自治州景洪市の周辺集落にみる 集落環境の悪化についての考察
}

都市・農村のマージナルエリアにおける民族混住についての研究 その 2

\section{ANALYSIS OF DETERIORATION OF THE RURAL VILLAGE ENVIRONMENT IN XISHUANGBANNA, YUNNAN, CHINA}

A study on the mixed-ethnic living in the marginal area of town and country Part 2

\author{
菅野博 貢* \\ Hirotsugu KANNO
}

\begin{abstract}
The purpose of this study is to claify the process of deterioration of the rural village environment that is influenced by inflowing population. The results can be concluded as follows:

1) In the process of ubanization, the life of indigenous people has drastically changed and in view of the disposal of waste matter in village, illegal abandonment has emerged in many places.

2) In indigenous traditional life style, their livestock disposed garbage and excretion, so there was no need to have garbage pit or toilet in village. Therefore the existence of livestock is important to maintain the environment of the village.

3) In accordance with increasing number of Han-Chinese, indigenous peoples began to use brick and built brick wall around their houses for security. In this process, the places where livestock could move freely were limited and that makes difficult for the livestock to dispose the waste matter. This study suggested that the building brick wall affected village environment severely.

4) For the future planning of the devoloping rural area, control of the inflowing population, making rigid policy for agiculture, and maintenance of the public peace and order will be indispensable issue.
\end{abstract}

keywords :inflowing population, marginal area, village environment, mixed-ethnic living, Xishuangbanna, Yunnan 流動人口, マージナルエリア, 集落環境, 民族混住, 西双版納, 雲南省

1.はじめに

(1) 研究の目的と対象地域の背景

本研究で対象とする西双版納夕イ族自治州（以下，西 双版納と略す）の州都である景洪は，メコン川流域の 「成長の四角形」"の中心都市として，急激な拡大を続

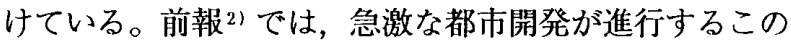
地域への移住者達が，少数民族の居住地域に自らの居住 地を拡大していくプロセスについて考察を試みた。本論 では，その結果として急速に悪化している集落の衛生環 境を分析し，なぜ環境の悪化が引き起こされているのか， その悪化の構図を明らかにすることを目的とする。

本題に入る前に，この内陸地域での急激な開発が行な われている要因ついて質問を受けることが多く，また， 単に観光開発の影響であるとの誤解も多くあったので， ここに少し紙面を割いて地域開発の背景を簡単に整理し ておきたい゙。

まず中国側の開発要因には，中国（雲南省）が夕イの
バンコクに直接至る輸送路として, 西双版納から夕イ北 部へのルートを模索していることがある。このルートに 関しては，既に80年代の終りからアジア開発銀行 (ADB) の援助のもとに道路建設が進められていたが，94年 4 月 には，同ルートの鉄道建設もメコン川流域におけるADB の優先開発プロジェクトに選定され，関係各国の合意も 行なわれた。また，94年1月のタイ，ラオス，ミャンマ 一を含む四ヶ国経済貿易投資協力会談によっても，この 地域の国際的な共同開発について合意され，開発の環境 は整ったといえる。さらに，西双版納を含む国境地域の 観光開発を進めることによる外貨の獲得と，辺境地域で のケシ栽培の撲滅，及び新たな雇用機会を生み出すとい う目的も中国側が開発を進めるうえでの強いインセンテ イヴとなっている。そして，これらの開発の中国側の拠 点として, 景洪の都市開発が80年代後半から進行し, 空 港建設やメコン川の河川港建設が実施されたのである。

タイについては，現在バンコクへの激しい一極集中に

\footnotetext{
* 財団法人国際開発センター 博士(工学) International Development Center of Japan Ph.D., Dr. Eng.
} 
苦しんでいるが，チェンマイからチェンライにいたる北 部地域での経済活動が活発化することによって，バンコ クに過度に集中している経済活動を分散させる狙いがあ る。これは急激な成長が見込まれ，また巨大な市場とも なりうる中国の存在を強く意識したものであるととも に，ドイモイ (刷新) 政策で経済が活性化しているべト ナム市場へのルートをも視野にいれたものであり，バー ツ経済圈は近隣諸国に拡大していると言われている。ま た，タイは急激な工業化の進展によって工業用電力の不 足をきたしているためにラオスから電力供給を受けてい るが,これまでメコン川流域開発の合意がなされなかっ たために，ラオス国内ではメコン川本流に直接影響を及 ぽす地域での発電は行なわれなかった。今後メコン川流 域の開発が合意されて開発が本格化すれば，より安定的 に巨大な電力の供給を受けられるため，この地域の開発 に積極的な姿勢を見せている。ケシ栽培については関係 各国とも共通であるが, 発展途上国の優等生といわれる タイにとっては，特に解決したい問題であるといわれて いる。その他，雲南省南部との文化的なつながりもタイ からの投資を促している要因であるといわれている。

ラオス，ミャンマーはともに近年になって経済開放政 策を目指すようになり，特にミャンマー一雲南省間の国 境貿易は近年非常に盛んになってきている。ラオスはオ ーストラリアからの無償援助によって 94 年 4 月に完成し たタイーラオス友好橋や，現在フランス，日本の協力で 進められている第二友好橋の建設によって, 夕イとの経 済的な結び付きを強めている。その他，ADBが積極的に メコン川流域の開発調查にのりだしたことや，アジア太 平洋連絡協議会（ESCAP）が94年に「新アジアハイウエ イ」のルートとしてこの地域の関係各国の合意を取付け たこと等々，数多くの要因により，「成長の四角形」の 中心都市としての景洪は, 中国沿海地方の大都市にも劣 らないような急成長を遂げ，周辺地域の余剩労働人口を 吸収しているのである。

\section{（2）研究の枠組みについて}

本研究を発表するにあたって, 基本的に異文化社会を 対象とするにあたっての集落や建築における名称研究の 必要性について指摘があったので, ここで研究の枠組み とともにその点に対して補足整理したい。本研究は人類 学的アプローチによる異民族社会の理解を目的とすると いうよりも，中国や東南アジアの各地で普遍的に発生し ている急激な経済発展に伴う地域開発上の問題点を, 具 体的な事例をもとに明らかにすることを目的としてい る。したがって，例えば本論で取り上げる集落内の廃棄 物の問題にしても，「廃裹物（ゴミ)」や「ゴミを捨てる こと」を現地民族語では何と称し，それは文化人類学的 にどのような意味を有するのか, 消費文化は上位文化で ある漢族によって持ち込まれたものか，などの議論より
は，実際に発生し，梁刻化している集落環境の悪化がど のようなプロセスを経て発生したのか，今後どう処理さ せるべきか，について考察する。その点では，我々日本 人がこれまでに経験してきた問題と共通の土壤で計られ る点も少なくない。

また, 本研究では, 経済発展に伴って急速に拡大する 都市とその周辺に位置する集落の関係を軸に，市街化に よる居住空間の変化を個々の住宅内部の変化にまで及ぶ ミクロなレベルで追跡調查している。本来, 先住少数民 族の集落には何ら加の方位感や住宅建設に関わる取り決 めがあることは想像されるが，ここで対象とする都市周 辺の集落の変化に扔いては，先住民族が住宅を改変する にあたっての経済的なインセンティヴが非常に強く，し かも本研究で示す通り想像以上の速度で変化している。 そのため民族の方位感等が数年の内に大きな変化をきた し，その影響で住宅形態の改変が進行したとは常識的に 考えにくい。このような観点から, 本研究では対象集落 で確認される物的な変化のみをできるだけ正確に記録 し，その現集のブロセスや背景を明らかにすることに主 眼をおいている。これらの点を明確にした上で，最低限 名称研究上の整理も行うものとする41。

\section{（3）調査と調查対象集落について}

本研究は1987年初頭にこの地域の高床式住居を視察 したことに端を発する。その後，先住少数民族の集落環 境の変化のメカニズムを明らかにすることを目的とし て，1989年，91年，93年，95年のいずれも9月～12月 の間に，後述する 3 集落の住居の悉皆調査を試みるとと もに，それら集落に膦接する都市周辺地区の環境の変化 について記録している5)。また，93年9月〜11月には新 中国成立（1949年）直後に移住した農民の動向調査, 94年の3月〜 5月には，対象集落と市街地に居住する夕 イ族及び主に市街地に居住する漢族に対する居住環境の 変化についての意識調査，94年の3月〜 5月と 95 年の 12 月～96年 1 月には近年の流入者に対する動向調查，及び 意識調査を行なっている。これらの調査は, 主に雲南民 族学院の元講師と卒業生等の協力を得て実施した。本論 はこれらの調査結果を分析し，考察を加えたものである。

対象地域は中国雲南省西双版納夕イ族自治州の州都で ある景洪周边であり，対象集落は景洪からほほ南にのび る曼听路に沿った 3 集落，曼景蘭，曼听，曼竜晃である。 集落人口は1982年の統計で曼景笨804人, 曼听 447 人, 曼竜寛450人となっている6。

既述の通り, 景洪は中国辺境開発の重点地区として, 特に1980年代半ばから急激な都市開発が推し進められ てきた。景洪に長く住んでいる人々の証言では，1984 年の対外開放の頃までは現在の州政府を中心に半径 100 $\mathrm{m}$ 程度の範囲しか道路の整備が倠んでいなかったという ことであるが，筆者が最初に訪れた 87 年の初頭もこれら 


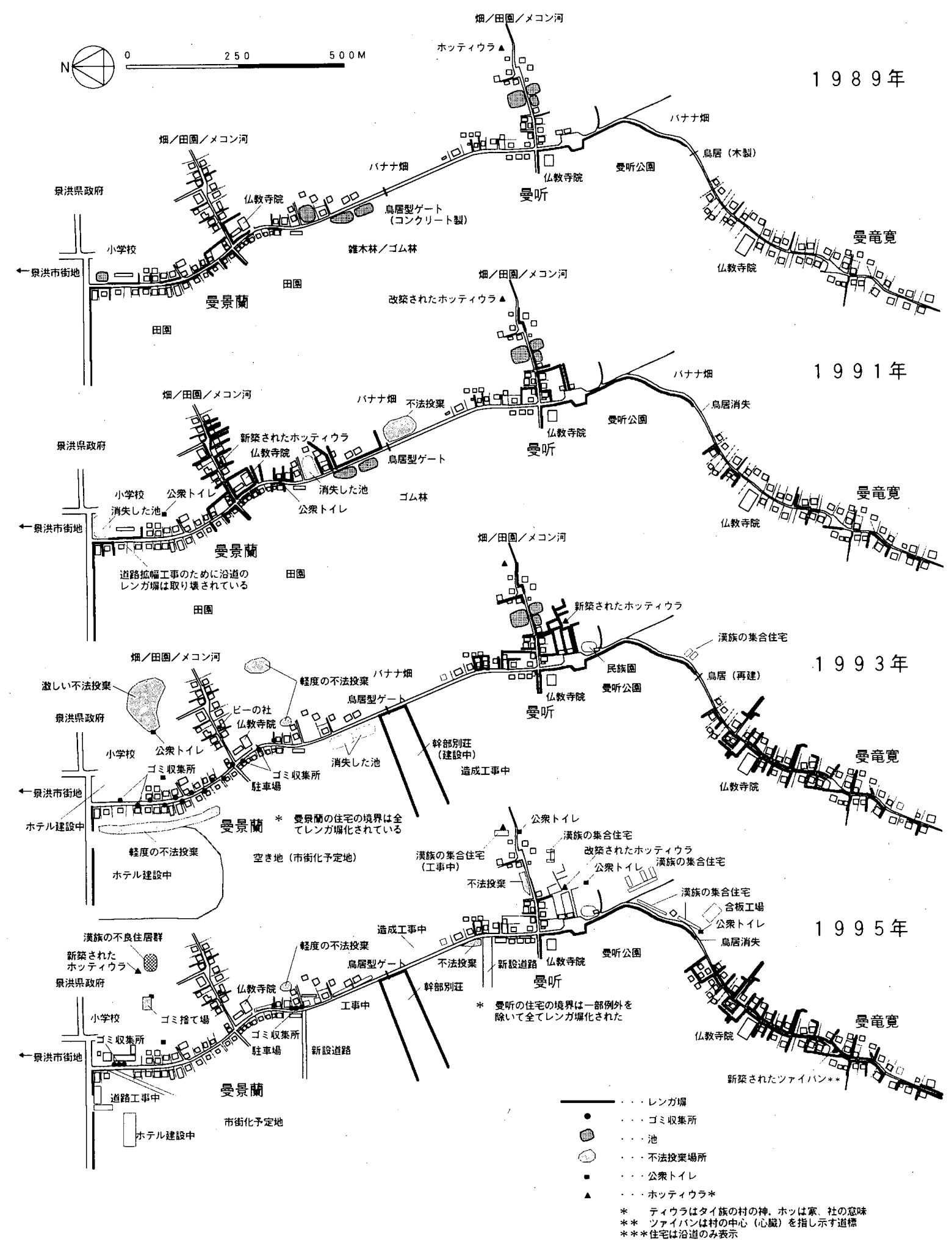

図1集落幹線沿道の変化（住居は曼听路と集落幹線沿いのみ表示）

の証言と大差ない状態であった。しかし，その後の数年 間の変化は極めて急激であり，89年の調查でまだ独立し た農村集落と呼べた曼景蘭は，93年の調査時には完全に 景洪の市街地の一部と化している。

対象とした 3 集落のうち，景洪の市街地に接している
曼景蘭から約 $1.5 \mathrm{~km}$ 南下した所にある曼听，さらに約 $1 \mathrm{~km}$ 南下した所にある曼竜寛は，市街化の影響の程度が それぞれ異なっており，その変化を段階的に見せてくれ る。本研究では，この3集落の1989年～95年における 市街化の漸進的変化に着目し，市街化に伴う集落環境の 
変化のプロセスを追跡調査している。

\section{(4) 先行研究}

混住に関する先行研究は前報で取り上げたので, 途上 国の都市，集落の環境問題についてのみ記述する。

1992年にブラジルで開催された「環境と開発に関す る国連会議」（地球サミット）に前後して，一般の関心 の高まりとともに多くの地球環境に関する出版物を目に するようになった。だが，途上国においては，その具体 的統計データが未整備であるために，都市の大気污染な ど人体に比較的直接的な影響を及ほし，且つデ一夕を比 較的容易に測定できる範囲の報告に限定されがちであ る。そして, 環境污染の問題を定量的に分析した研究は まだ少数であり，OECDやJICAの報告書，或いはアジア 経済研究所を中心に行なわれている研究が小量ながら貴 重な資料を提供している状態である7。また，中国の廃 菓物問題に関しては，その実態はほとんどつかめておら ず，「正確なマクロの資料ができるまでは，まだかなり の時間が必要81」であるとされている。

\section{2. 集落環境の変化}

\section{(1) 集落環境の変化の概要}

当地域に筆者がはじめて訪れた1987年初頭には，市 街地に最も近い曼景蘭でさえもまだ舗装道路が一本もな く，自然の中に溶け込んだような集落景観を呈していた。 本格的な調査を開始した89年頃でも，豚や鶏が道路を自 由に徘䧃し，住宅間の境界も簡単に割竹を編んだもので 仕切られる程度であり，非常に開放的な印象が強かった。 勿論，集落内にゴミの不法投菓などはほとんど見られな かった。しかし，その後91年に行なった集落調査の際に は，ゴミの不法投裹が小規模ながらも目につくようにな り，集落環境の悪化が進行し始めた。

91年の末から集落幹線である曼听路の拡幅と舗装工事 が曼景蘭で始まり，92年までには曼听まで一気に伸びて 沿道の集落景観を一変させることになった。沿道の高床 式件居はレンガ造の缯店に置き代わり，タイ族ぶ経営し ていたレストランのほとんどは漠族の経営者に貸し出さ れることになった。また，一般の高床式住居の床下には 多くの漢族が住み着くようになり，集落人口も飛躍的に 堌加したものと思われる。集落縁辺部での不法投率が激 しくなるー方で，93年の調查時には市街地に近い集落で ゴミの収集サービスが開始される。また 3 集落の西側に 広がっていた広大な田園は92年に一斎に用途替えが行な われて市街化予定地となり，93年から94年にかけて道 路等のインフラ整備が進められた。

95年にはコミ収集サービスが以前よりうまく機能しは じめたせいか，曼景蘭の不法投棄はやや鎮静化している ようにみえるが，曼景蘭を追うように曼听で不法投棄が 目立つようになった。また，各集落内部における道路舗
装が94年から95年の間に急速に進行し，特に曼景蘭で は側箠が掘られて生活排水を流すことが可能になった。 排水は一部途中の養魚池, 畑などを通過してメコン川に 流されている。曼竜寛では，95年時点でもまだ不法投棄 や生活排水による目だった環境悪化は見られないが，集 落に隣接して建設された合板工場の産業排水等は注視し なければならない。

\section{（2）集落環境の分析}

図 1 は，1989年〜95年の期間における集落幹線道路 の沿道の変化をまとめたものであり, 以下この図にそっ て集落環境の変化を考察していく。この図では, 沿道の 住宅のほかに不法投棄の行なわれた場所, 公采便所, 溜 池，レンガ塀の位置を中心に記入している。これらは後 述するように，いずれも集落環境の変化と梁く結び付い ていると考えられる要素である。

まず図中の変化を概観したい。この図で一番目につく のは，住宅周井のレンガ塀が急速に伸びていることであ る。89年には曼景蘭の曼听路沿いにしかなかったレンガ 塀が，91年には曼景蘭の奥と曼听に延び，93年にはほ とんど曼竜寛の奥までレンガ增が延びている。この変化 とともに，91年の曼景蘭にはそれまでなかったゴ捨て 場と公衆トイレが現われた。さらに93年には曼景蘭にゴ ミ収集所が設けられると同時に，ゴミ収集所のある曼听 路から遠い集落の縁辺部では，ゴミの不法投萧が激しく なっている。95年には曼景蘭の内部にゴミ捨て場が設け られ，93年よりも不法投萧は鎮静化しているようにみえ るが，新たに曼听で不法投棄が目立つようになった。

道路の舗装は，87年には全て幅員の狭い未舖装の道路 であったが，89年には曼听路が曼听まで荒くコンクリー トで舖装された。その後91年暮れから大規模な道路拡幅

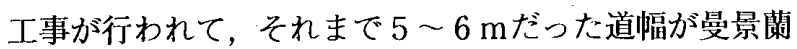
で15mに拡幅された9)。この道路の舖装化と共に, 次々 と道路沿いの溜池が消失した。一方，93年に入っても曼 竜寛の道路は未舗装のままであったが，95年には曼竜寛 の最奥まで道路の舗装が進み，自動車の進入が可能にな るとともに漢族の居住も曼竜寛まで広がった。さらに漢 族の集落への移住が進むにつれて公采トイレが堌える一 方で，夕イ族の集落の神様であるテイウラ101の社や集 落の中心を象徴するツアイバンいの数も增えている。

以上の変化の起きた原因を順を追って分析する。

レンガ垪については，住人への直接の聞き取り調查か ら，景洪の市街化にともなう周辺集落の治安の悪化がそ の設置を促している，ということが推测された。事実， レンガ算そのものの形態も上部にガラスの破片を埋め込 んだものが多く，塀につく罪も一見物々しい頑丈な鉄製 のものであり，外に対する警戒感の高まりを感じさせる。 「泥棒が增えた」ということは91年頃から度々聞かれた が，95年の調查時には実際に床下に置いていた大型のト 
ラクターを盗まれたという家さえあった。この治安とレ ンガ堀の関連は，まだレンガ垃化されていなかった曼竜 寞における91年調查時の番犬飼いの大流行と、レンガ榐 化された後の93年調查時の番犬の消滅によっても哀付け られるのではないかと考えられた ${ }^{21}$ 。また，床下に数十 世滞分もの賃貸部屋をかかえる夕イ族住居の場合には， 「必ず留守番を一人扔くようにする」ということも聞か れた。

さらにこのような治安に対する不安が増す一方で，夕 イ族の生活が急速に富裕化していることも事実である。 95年時にお打る 3 集落の過去一年の現金収入について調 查した結果では，その多くが5,000元を越え，1万元を 越えるものも珍しくない 3)。特に床下部屋を貸している 世带の収入の高さは注目に値する (図 2 , 図 3 参照)。 実際の生活に扔いても，89年の調查時にはほとんど見ら れなかった 1 セット数千元以上もする大型の家具が，93 年の調查時には広く普及している状況がみられ，95年時 では所有していない世带のほうが珍しいほどである。ま た，自転車でさえ貴重な中国にあって，モーターバイク を所有するタイ族も多く，大型の農耕用トラックも珍し くなくなっている。このような夕イ族の富裕化もレンガ 㒛や物々しい屝に結び付いていることが推測される。

レンガ坆がこのように普及した背景には，その材料と なるレンガが急速に普及したということも見逃せない。 森林破壊の進行と森林の保護地域の拡大，かつて森林だ った山地がゴムのプランテーションに変化したことによ る木材の不足と木材侕格の高滕, 都市建設の需要から大 規模なレンガ工場が郊外に建設され，安価なレンガが普 及したこと等，様々な要因がレンガ垪の設置を促進させ る原因になっている14)。実際，91年以降に建設された 住宅に扔いては，それまでのような木の柱を用いる住宅 よりも，レンガ製の柱を用いる住宅が数で上回り，93年 の該查時においては，高床式住居の形態はそのままに， 床梁に鉄筋コンクリートを用いて壁にまでレンガを使用 する住宅が現われている（図 5 参照)。これらの事は集 落全体にレンガが普及していることの一端を示している と䒓えられ，その中でそれまでの竹や木製の塀がレンガ 挥に置き変わっていったものと捉えることもできる。

不法投棄の出現と，その後のゴミ収集所の出現は，か つての集落内部における物質循環の流れが大きく変化し たことを示しているといえるだろう。この背景には，交 通体系の整储が飛踾的に進み，流通経済が発達したこと によって，他の地域から大量の工業製品が流入し，かっ ての自給自足的生活が根本的に変化している状況がある が，これは初期の曼景蘭の不法投裹や最近の曼听の廃棄 物に石油製品が目立つことからも推测される。

一方，このような流通経済の発達により，農作物が経 済作物に急速に転換されていることが推测される。西双

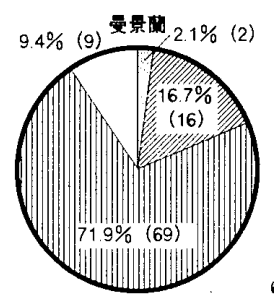

不明 (4)

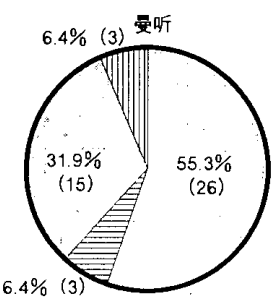

不明 (3)

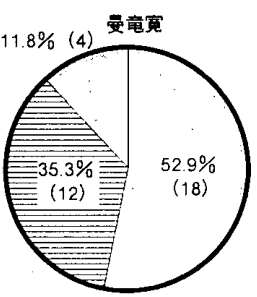

不明 (7)

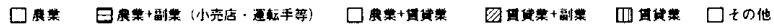

図 23 集落住人の主な収入源（95年）*調查住宅数は註3) 表1の95年の筧を参照。（）内は実数。「不明」は比率に含めず。以下图 4 まで同じ

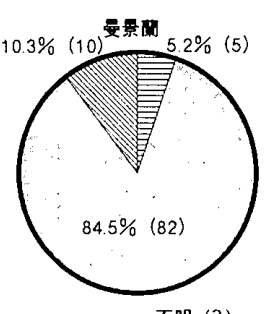

不明 (3)

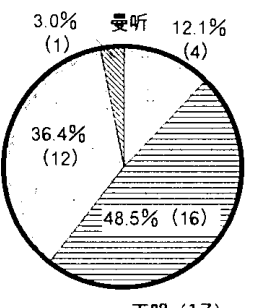

不明 (17)

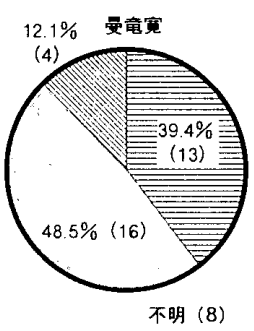

因 1万元以上
図 33 集落住人の過去 1 年間の所得（95年）

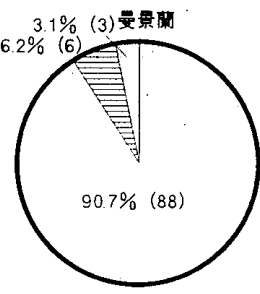

不明 (3)

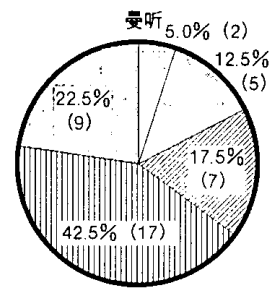

不明 (10)

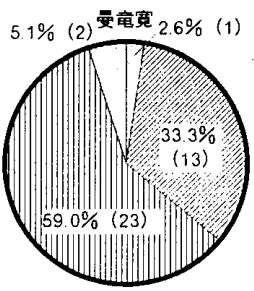

不明 (2)

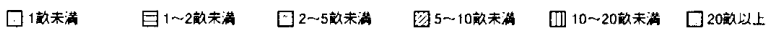

図 43 集落住人の所有する農地面積（95年）

*1畧 (ムー) は土地の面䅡を表す中国の単位で6.667a（アール）に当たる
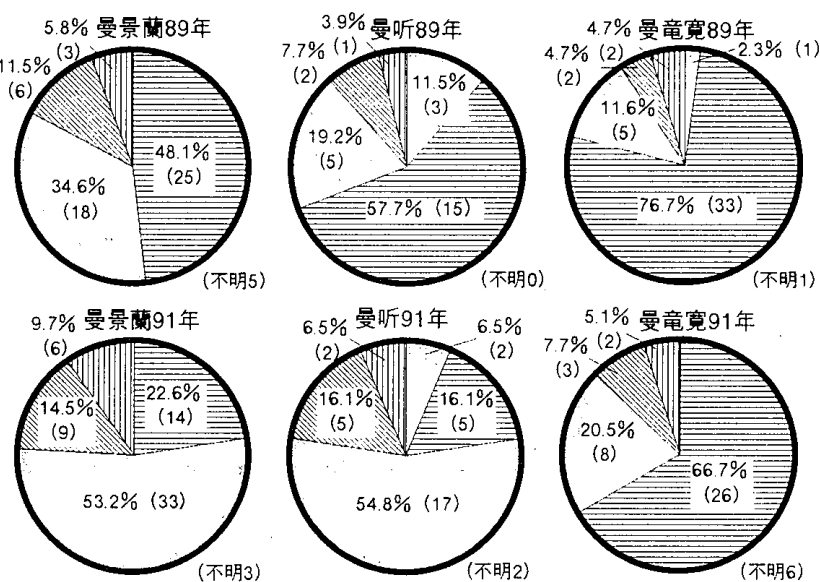

曼景菊93年

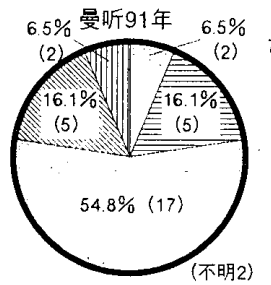

$5.1 \%$ 曼竜宽 91 年

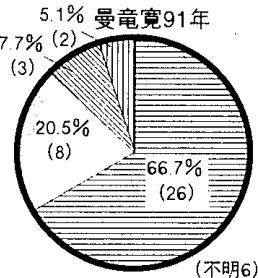

$5.9 \%$ 曼童賀93年
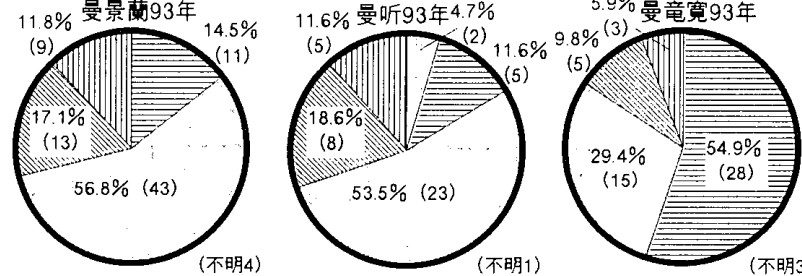

柱材 /壁材田レンガ・木材併用/木材

口竹材/竹材四レンガ材/木材

目树ノ木材 孟レンガ材ノレンガ・コンクリート材

図 5 住宅建材におけるレンガの普及（柱材／壁材）

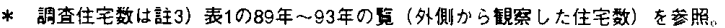
（）内は实数。不明は比舞に含めず。 
版納全体では，換金作物としてのゴムと茶の生産が盛ん になっていることが統計的にも明らかであり，景洪周辺 の山地のほとんどがゴム林か，ゴム栽培には標高の高す ぎるところは茶の栽培地となっている15)。統計資料は 入手できなかったが，このような周辺の山地ばかりでは なく，低地においてもそれまでの米を中心とした複合的 な宸作物の生産から，トウガラシやトマトをはじめとす る換金作物の生産に切り替える農家が目立っている。こ のような農作物の生産形態の変化も, 農村集落の環境に 大きな影響を与えていると考えられる。

調查期間中に沿道の 4 つの溜池が消失したが,これら は農業用水の必要がなくなったことなど，沿道を取り巻 く環境が大きく変化したことを示唆している。溜池の消 失に関しては，水道が普及したことと，沿道の地価があ がったために溜池を埋立ててより収益のあがる建築物を 建てようとしたこともその要因であったと考えられる16)。

以上に加えて，曼景蘭の西側に広がっていた広大な田 園も92年に一斉に用途替えが行われ，暫くは市街化予定 地として広い乾燥した空き地になっていた。この農地の 用途替えを機に離農した集落住人も多く，離農者の增加 は，対象 3 集落の住人の主な収入源や所有する農地面積 の差となって現われている（図 2 , 図 4 参照)。96年1月
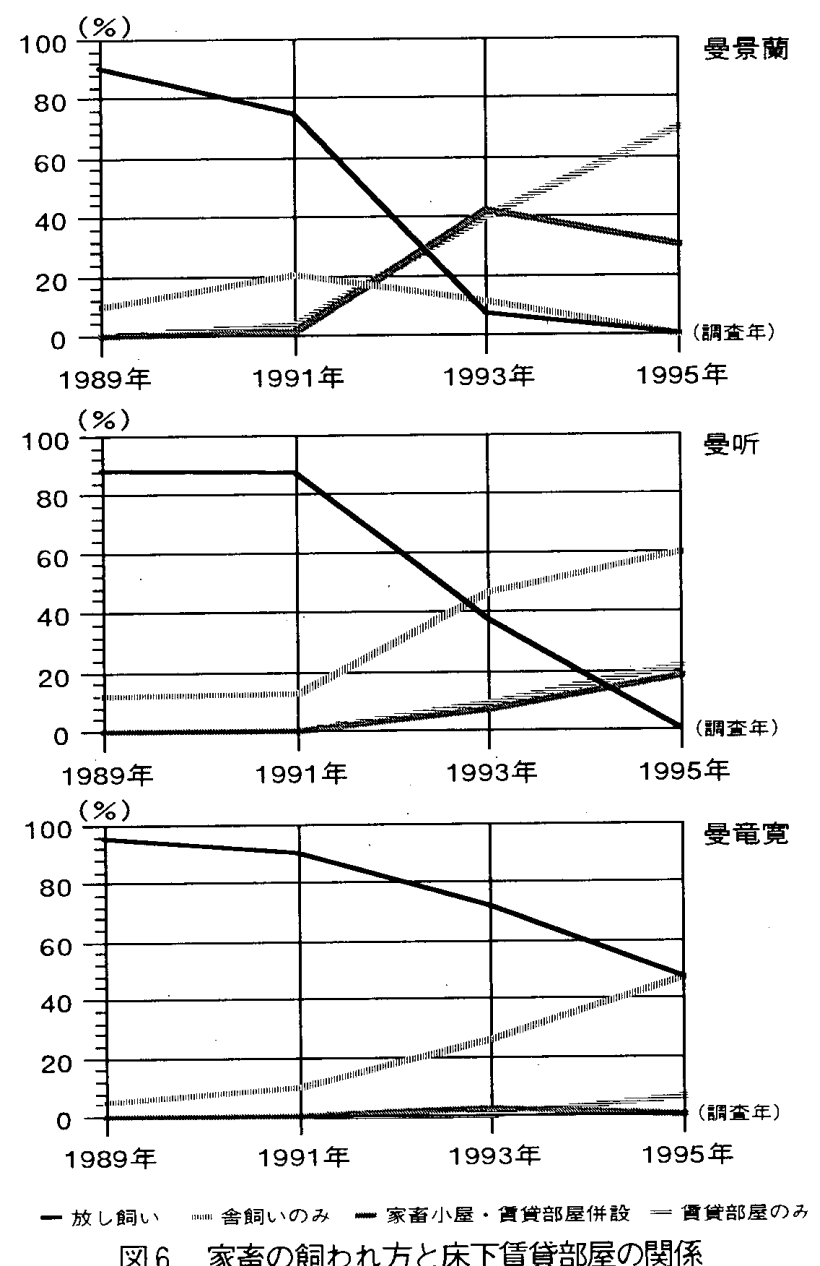

図 6 家畜の飼われ方と床下賃貸部屋の関係
現在ではこの土地における道路などのインフラ整備も進 み，3つの大型ホテルと新しい市場か建設され，新なな 市街地が形成され始めている。そして当然ながら，この ような隣接する広い土地の改変は, 集落環境全体に影䈉 を与えていることが推測される。

\section{（3）流入人口の増加と集落の衛生環境の悪化について}

集落の環境悪化を招いている最大の原因は，不法投菓 される廃棄物の量が著しく増玑したことであるが，この 廃棄物の処理に関しては，流通経済の発達にも増して流 人人口の急激な増加と, それに伴う家蓄の飼われ方，そ してその役割の変化が大きな影響を及ほしているのでは ないかと考えられた。なぜなら，93年頃までの曼竜寛や 91年以前の曼听などの住宅では，まだ伝統的な自給自足 的生活を比較的よく残しており, 人間の排出する生ゴミ などのほとんど全てから時には排泄物に至るまで，住宅 周辺で放し飼いにされている豚が処理している様子を日 常的に観察することができたからである。

床下空間の使われ方の変化についてみても，以前は積 極的な用途には使われておらず，家畜の徘䧃する空間で あったものが，現在では家畜小屋が設置され，それに隣 り合うように空間が仕切られて, 主に漢族の移住者達が 居住する空間となる場合が増加している。この休下の部 屋は，当初は木の板で囲っただけの簡単なものであった が，その後この居住形態が定着するにつれてレンガ壁の より恒久的な煠間に変質してきており，さらに最近の住 宅建設におろいては，伝統的な高床式住居の形態を捨てて， はじめから 1 階部分を貨貨アパート用の部屋として建設 する場合も珍しくなくなってきているい゙。

このような住宅の変化にともなって，かつてはほとん ど放し飼いにされ，住宅の敷地の内と言わず外と言わず 自由に行動していた豚等の家畜は，レンガ垪化によって 住宅の敷地内だけに行動範囲を限定されがちになり，家 畜小屋の設置によってその内部だけに行動範囲を限定さ れることになった。さらに床下に人間が住むことになっ て，家畜のスペースは完全に駆逐されてしまったと考え られる。図6はそのような家畜（豚）の飼い方の変化と 床下空間の変化の関係を集落ごとに示したものである。

曼景蘭では，豚の放し飼いは89年から91年の間には やくも減少し始め，その後は急速に減少して93年時点で 既にほとんどなくなっている。それに代わって舎飼いが 増え，また床下部屋の設置も急速に進んで93年には家畜 と床下部屋が併設される場合と，床下部屋のみの場合が ほほ同数になった。そして，95年では床下部屋のみの場 合が約 $70 \%$ 占めるようになる。曼听では91年から 93 年の間に放し飼いと舍飼いの割合がほほ同数となり，95 年にはほとんど舍飼いに置き代わると同時に，放し飼い は行なわれなくなった。また，床下部屋の貨貸も93年以 降増加する様子が伺われる。曼竜竟では曼听から約 2 年 
遅れで放し飼いと舎飼いとがほぼ同数となり，95年には 市街地に近い側の一部の住居で床下部屋の賃貸が始まっ ている。

ここで注目したい点は, 先の図 1 にみる曼景蘭，曼听 における不法投菓の激化と，家畜の舎飼い及び床下部屋 の增加が軌を一にしていると考えられる点である。この 点について集落環境の悪化という観点からみると，豚の 舍飼いによって集落内で处理される生ゴミの量が減少し たことと，集落人口が增加して吐き出される廃棄物の量 が増加したことが直接の原因として考えられる。

93年の曼竜寛における簡単な半日のモニターによって も，家畜小屋もレンガ嚗もない住宅の豚は，その飼い主 の家から半径 $100 \mathrm{~m}$ 以上の範囲に行動圈を持ち，人から 与えられるバナナの幹を臼で潰したものから, 生ゴミ, 人翼まで摄取していた。だが，舎飼いの同では人間の出 す生ゴミよりも人工飼料を多く掑取しており，さらに家 畜の消滅した住居では，かつては貝重な飼料であった生 ゴミが，ゴミ収集所に捨てられている光景も珍しくなく なっている。このような家畜の役割の変化が，集落内に 不法投裹を出現させたりゴミ収集所の設置に慗がってい ることは明白であろう。しかしながら，このようなゴミ 収集所の設置も車の入りにくい集落内部には置かれず， サービスの受けられるのは大通りの曼听路に近い住宅だ けであり，前述のように集落縁辺部一带にはゴミが不法 に投棄され，集落の衛生環境を著しく悪化させる結果と なっている。また，面接調查の調查員からの報告では， このようなゴミ収集サービスの片寄について不公平感を 訴える住人も多いということであった。

一方，このような集落人口の急激な增加は，集落内の 公衆トイレの出現という形でもその影響が現われてい る。トイレを必要としなかった夕イ族の生活様式の中に 異なる生活様式をもつ漢族が流入した結果，夕イ族も卜 イレを使うようになったと考えることもできるが，何よ り流入者の数が先住民の集落人口をも大きく上回るほど 增加していることが原因であろう。床下の流入者も含め た正確な統計はないが，曼景蘭のようにほとんどの夕イ 族世带が部屋の貨貸しを行なっている集落では，既に夕 イ族の全集落人口を大きく上回っていることが推測され る18)。

以上の不法投萧の問題に加えて，生活排水も場所によ っては強い悪臭を放ち，集落環境を悪化させる原因にな っているが，曼景籣では地形がメコン川に向かってだら 下がりになっていることもあって水流が滞りにくく，特 に大きな䦓題とはなっていない。しかし，近い将来曼听 や曼竜宽に市街化が進行した場合，曼景蘭のような地形 条件を備えていないために，不法投棄以上の問題となる ことが予想される。また，曼景蘭においても，このよう な未处理の生活排水の河川への流出は広域的な污染につ
ながる可能性があり，将来的には何らかの対策が取られ なければならないだろう。

\section{3. まとめ - 居住環境の変化と集落環境の悪化}

以上, 集落環境の変化について, 顕在化している現象 を手掛かりにその変化の要因を考察してきた。既に見て きたように，集落環境の悪化は様々な要因が相互に関連 しながら連鎖的に変化することによって引き起こされて いる。調查で垣間見ることのできる現象の他に，住民の 衛生観念の変化や生活様式の変化といった, 容易には計 ることのできない変化も重要であろうが，これまで観察 された現象を手掛かりとすると, 図 7 の様な連鎖的変化 として集落睘境の悪化のプロセスをまとめることができ るのではないだろうか。

この図のとおり，市街化による流入人口の増加に伴う 治安の悪化や先住民族の富裕化が，レンガ塀の建設を促 した。そのレンガ塀が住宅とその周辺環境との関係を分 断することによって家畜の行動を制限し，生ゴミ等の廃 萧物や人間の蒋尿の処理を難しくする。そしてこれらの 家畜は家畜小屋に入れられたり床下に住み着いた流入者 に取って代わられたりすることで人間の廃童物を処理す る役割を失い，廃杗物は不法投棄されたりゴミ収集所に 送られる。一方，床下に住む流入者は益々その数を増し， 公衆トイレ，下水用側溝などの施設の必要性を促してい る。また，夕イ族はその床下住人からの賃貸料収入によ って離農する傾向が強まり，周辺の耕作地が市街地に転 用されていることもあって，集落の農村的性格は急速に

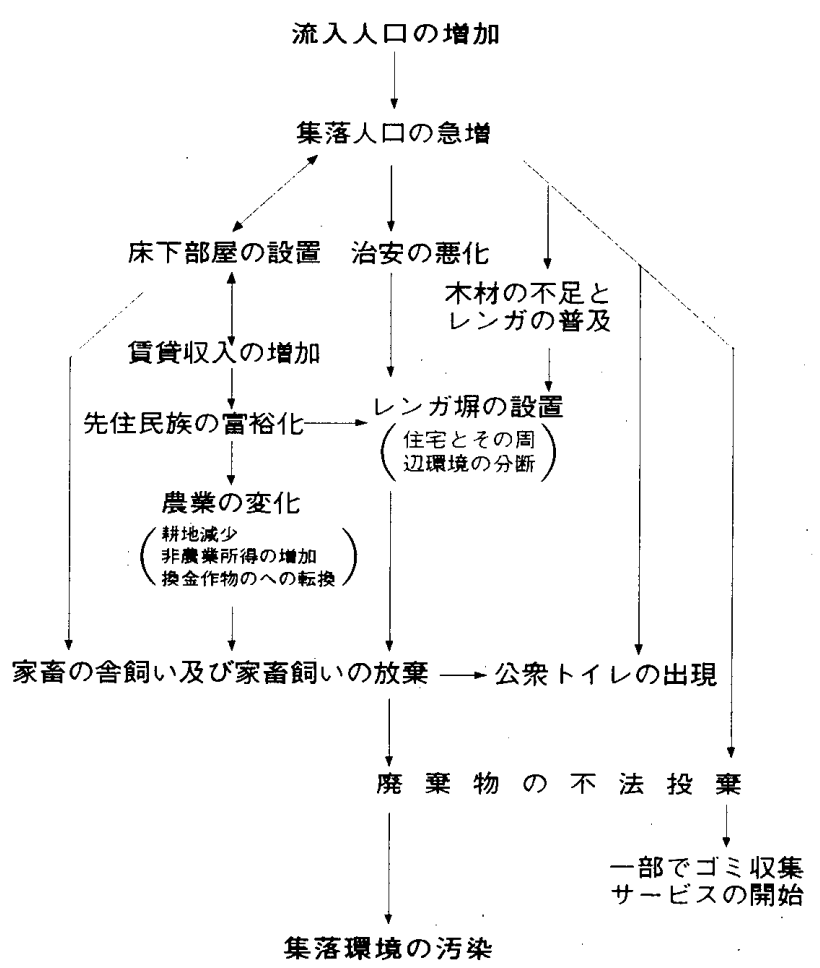

図 7 集落環境悪化の構図 
失われる。

このような集落における物質的な循環について論じる には，さらに多様なスケールにおいてより詳細な奏証的 データの蓄積が必要となろう。その点については, 本研 究の課題として今後ともデータの収集を行なう予定であ るが，現時点におけるまとめとして以下のように整理す る。

1）西双版納の経済的発展にともなって州外から景洪に 移住する人口が急增し，景洪の都市域は急激に拡大して 周辺の集落をもその域内に取り込もうとしている。この ような市街化の進む中，先住民族の生活にとって流通経 済や交通体系の整備等のプラスの影響の他に，治安の悪 化などのマイナスの影響がもたらされている。そして， このような社会的な影響は先住民族の居住空間にも大き な影響を与えており，具体的には高床式住居の床下空間 の変化，堅牢なレンガ塀の出現などにつながっている。

2) 集落形態や住宅形態に起こった変化のなかでも, 特 に流入者の高床式住居の床下への居住，レンガ塀の建設 と家畜の飼い方の変化は，廃棄物の処理過程の上で大き な影響があったのではないかと考元られ，それまで不必 要であった集落住人の廃玄物，屎尿などの処理施設が必 要とされるようになった。これらは結果的に集落縁辺部 で激しい不法投棄をまねき，集落の衛生環境を悪化させ ている。

3 ）流入者の数が増加するにしたがって，共同トイレや 排水溝などの施設がつくられるようになったが，生活排 水などは未处理のままメコン川に排水されており，今後 広域的な污染につながる可能性がある。また，収集され た廃棄物の山林への投棄も大きな問題となっている。現 在尿尿は畑に撤かれているが，集落周辺の耕地が急速に 隇少している中で，今後も需給のバランスが保たれるの かは疑問である。既に排水処理施設や尿尿処理施設の設 置が検討されるべき段階にきているといえる。

4）ゴミ収集が開始された集落においても，集落内の道 路が狭くてゴミ収集車が入れないために，大通りに面し た住人以外はその+ービスを受けることができないとい う, 集落形態そのものに関わる根本的な問題がある。そ のため集落の縁辺部では，ゴミの不法投棄がますます激 しくなる傾向がある。また，このような状況に不公平感 を抱く住民も少なくない。市街化の進んだ集落では，ゴ ミ収集車が入れるような集落内の道路ネットワークを考 慮すべき時期に来ているといえる。

5）本論の結論である図 7 にはまだ実証しなければなら ない点が多く含まれているが，この図に示すような集落 環境の悪化の構図を仮定すると，今後急速な開発が進む 都市周辺の集落計画に際しては，i）流動人口のコントロ 一ル, ii) 都市化に伴う治安の維持, iii) 地域産業構造の
監視，特に良好な農業環境の維持，なども重要な計画課 題になるといえる。そして，これらの状態を量る手段と して，a) 先住民族と流入者間の混住状況（特に集落人口 の增加状況)，b) 先住民族の農業環境の变化，c）屎尿処 理や生活廃裹物の流れの変化，などが有用なバロメータ となりえるのではないかと考える。

註

1）タイのチャチャイ元首相が提唱し，その後成長の三角形（シンガボ 一ル，マレーシア，インドネシア）に此較して一般的に用いられるよう になった。

2) 参考文献 $32 \%$ 。

3）参考文献13）-21）などを参照。

4）タイ族集落、住宅等の名称研究については，参考文献29）に詳しい が，註10)，11）に述べるように地域間の差異が大きい。

5) 調査住居数は，表1のとおりである。93年の調查までは基本的に集 落幹線沿道の住宅のみを対象としていたが，それは調查能力の限界のほ かに，曼听，曼竜寛が集落幹線沿いに線上に発達した集落であったため である。だが，集落の桩大と共にこの2 集落も曼景闌のような面的な広 がりをもってきたため，95年からは完全な全戸調査に切り替えた。95 年の調查住宅数の增加はそのためであり，95年の外部からの調査数は， そのまま集落の全夕イ族住宅戸数を示す。

表了調查住宅戸数

\begin{tabular}{|c|c|c|c|c|}
\hline $\begin{array}{c}\text { 調查年 } \\
\text { 对象集落 }\end{array}$ & 1989 年 & 1991 年 & 1993 年 & 1995 年 \\
\hline 曼景蘭 & $57(31)$ & $65(51)$ & $80(44)$ & $184(100)$ \\
\hline 曼听 & $26(19)$ & $33(30)$ & $55(46)$ & $92(50)$ \\
\hline 曼竜寬 & $44(29)$ & $45(34)$ & $54(43)$ & $76(41)$ \\
\hline
\end{tabular}

* 調查住居数は住宅の外側から観察した住居数であり、（）内は そのうち住居内部の記録及ひ住人への面接調查を行なった住居の 数である。

6.).集落人口は，雲南省人民政府経済計画局の瀻貝からのヒアリングに よる1982年度の統計である。82年以降の集落人口の統計は公表されて いない。

7）参考文献6）-10）など。

8）参考文献 S）上り。

9）当然ながら曼听路沿いの住宅は，そのほとんどが道路拡幅の影罯を 受けた。住宅を半分削られたり，完全に立て替えを余儀なくされた住宅 も少なくなかった。

10）ティウラは夕イ族の土着の神であるが，曼景蘭では，テイウラロン (「ティウラ」は神，「ロン」は「大きい」を意味する)，ティウラキェン (=ティウラハン?「キエン」は「水」「ハン」は「琹」を意味するとい うことたが、この二つの呼称は一つのティウラに对して用いられていた） の)二つのティウラが, 曼听ではティウラロン, ティウラマン（「マン」 は「村」を意味する)の二つが確諗され，曼竟宽では一つも確詒されな かった。これらは何れも特定の家によって世警的に管理されている。テ イウラ相互の関係やティウラと同じように信仰の対象となっている「ビ 一」との関係等については，意見百出で特定することができなかったの で今後の課题としたい。参考文献29）によると，西双版䄪の夕イ族集落 の中では比較的古くから存続していると言われる曼海村で「ティウラへ ン」「ティウラマン」「ティウラモン」の存在を確認しているが、このよ うな村の神に対する呼称等は集落ごとにかなり多㥞である。これらを整 理するためには夕イ族居住地域全体を対象とした調查が必要であり，や はり今後の研究課題としたい。

11）ツアイバンは集落の中心を意味するものであり，刘象 3 集落の中で は曼竜筧でのみ確認された。しかもこのッァイバンは95年に新しく作ら れたものである。参考文献 3 ) では「Zaixin（ツァイシン)」という呼称 を採取しているが，文献中の写真から曼竜宽のッァイバンと同じものを 
さしていることが分かる。参考文献29）では『留ンッァイマン」とい う集落の中心広場に「フォンティウラ」がある」としているが，前記の ティウラ同様に集落ごとにかなり多様であることが推測される。

12）曼竜宽における1989年の調査時では，番犬を飼う家はほとんどな かったが，91年の調查時には，ほほ全ての住宅で翻飼いがみられた。 だが，93年の調査時では，番犬を飼う家はわずか数件に激減した。その 後95年には再び增加傾向にある。91年の調查時に番犬飼いの理由につ いて直接尋ねたところでは，犯罪の增加をあげる住人がはとんどであっ to

13）雲南省の一人当たりの国民所得は，92年の統計で1,168元である。 参考文献31）上り。

14）景洪は盆地の中央に位置し，かつては周辺の森林が住宅建設の際の 木材の供給源であり，住宅を建設する祭には，親成や近所の住人が力を あわせて山から木を切り出し，村まで連んだということである。しかし， 現在では周辺の山林の木はほとんど切り尽くされて，それ以上の伐探を 整した保蓝区域になっている。また，1950年代の後半からこの地に入 植した漠族がゴムのブランテーションをはじめて以降，コム林の面積は 徐々に拡大し，現在では景洪周辺のほとんどの森林がゴム林と化した。 また，景洪の市街地の北側に接する山中に面積約 5 万 $\mathrm{m}^{2} に$ るふぶンンガ 工場があり，大量のレンガを製造している。このレンガ工場の土の採取 によって，山肌が数百㐂にわたって大規模に削り取られている。また， レンガを狫く際には大量の石炭を必要とするが，建材としての木材の採 取と同㥞に，レンガの製造もまた自然破壊をもたらしているといえる。

15）1956年頃から栽培され始めた西双版納におけるゴムの栽培面積は, 1963年までに6,129ha，1970年に18,274ha，1974年に27,215ha，1983 年に48,656haとなっている。参考文献 4) より。

16）気舜デー夕からも西双版納の乾燥化は毫付けられているが，森林面 稓の激減がその主な原因であると考えられている。参考文献23）上り。

17）既報，参考文献32）参照。

18）曼景蘭で行なった1993年10月の住宅の悉皆調查では，一世带あ たりの床下部屋の平均は3.89部屋であった。これに全世带数をかけると 床下部屋の粉数は700.2世带となる。一方集合住宅の世带数は 500 前後が 数えられたが, これを加えると約 1200 世带の移住者世带が集落内に存 在することになる。雲南省の一世带あたりの平均家族数は 1990 年で4.51 人（参考文献30）より）であるが, 移住者世带には一人世带も多く，こ の数字をかなり下回るものと思われる。仮に一世带あたりの家族人数を 2 人とすると集落内の移住者粉数は 2400 人，家族人数を 3 人とすると 3600人という数字が推計される。しかしながら，このような大まかな 推計を行なうまでもなく、タイ族 1 世带の住宅の床下に30人以上もの流 入者世带を抱えている場合が珍しくないことから，流入者人口が先住民 の人口を上回っていることは明らかである。以上のような人口增加の影

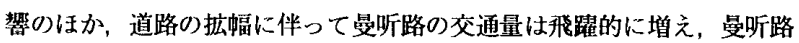
沿いに立ち並ぶ夕イ族レストランには，連日多数のバスにのった钼光客 が押し寄せるようになったが，当然ながらこれらのレストランから排出 される廃童物や排水も大きな割合を占めることが予想される。しかし， 廃亲物についてはレストランがコミ収集サービスを受けやすい幹線道路 に面しているので，直接不法投衰にはつながっていないものと思われる。

\section{参考文献}

1) Kunstadter,P.,Chapman,E.C. and Sabhasri, S. eds.: Farmers in the Forest, UP of Hawaii, pp402,1978 及び Kunstadter ,P. ,The Impact of Economic Development in Southeast Asian Tropical Forests, in Furtado, J.I. ed.,Tropical Ecology and Development, pp.65-72, 1980

2) 雲南省設計院粨：雲南民居，1986

3) Zhe Liangwen: The Dai - Or the Tai and their Architecture and Customs in China, D.K. Book House, 1992

4）張立舆垠編：西双版納国土程済考察報告，雲南人民出版社，1990

5）藍勇著：歴史時期西南経済開発與生態変選 (西南䂙究書系), 雲南
教育出版社, 1992

6) OECD:Implications and Modalities of Further Restricting Hazardous Wastes Exports from OECD Countries 1989

7）JICA有害廃棄物投亲調査第二次専門家チーム：ナイジェリア有害廃 亲物投亲現地調查報告書, 1988

8）藤崎成昭編：癹展途上国の環境問題, アジア経済研究所, 1992

9）柴田德衛, 加納弘勝螎：第三世界の摆境問題, アジア経済研究所, 1986

10）アジア経済研究所編：発展途上国環境問题総合研究報告書海外共同 研究 (中国)，アジア経済研究所，1992

11）小岀麗逸，藤崎成昭編：開発と環境一東アジアの経験，アジア経済 研究所, 1993

12）小島麗逸：都市化と都市問題（VI-X VII），中国経㴮，JETRO， $1993.8-1995.4$

13) Asian Development Bank:Indonesia-Malaysia-Thailand: Growth Triangle, Development Project, Volume I — VII , Asian Development Bank, 1995

14) Economic and Social Commission for Asia and Pacific:Asian Highway Network Development, United Nations, 1995

15) Economic and Social Commission for Asia and Pacific:Investment and Economic Cooperation in the Tourism Sector in Developing Asian Countries, Escap Tourism Review No.8, United Nations, 1991

16) Asian Development Bank:Subregional Transport Sector Study for the Greater Mekong Subregion, Final Report, Part I - II,Asian Development Bank, 1995

17) Economic and Social Conmission for Asia and Pacific:Environmental Impact Assessment for Inland Water Transport Development Projects in the Upper Mekong Subregion, Initial Environmental Examination Report, United Nations, 1995

18) Asian Development Bank: Asian Development Outlook 1995 and 1996. Asian Development Bank, 1995

19) National Urban Development Programme: National Urban Development Policy FrameworkZ,Final Report Volume 1 $\cdots 2$,National Urban Development Programme, 1995

20) Committee for Planning and Cooperation: $1975 \cdot 1995$, Basic Statistics about the Socio Economic Development in the Lao P.D.R., National Statistical Centre, 1995

21) Committee for Planning and Cooperation:LAO Census 1995 Preliminary Report 2 (results on the province and district level), National Statistical Centre,1995

22）環境庁地球環境部編：地球環境キーワード事典, 1994

23）吉野正敏編：雲南フィールドノート, 古今書院，1993

24）雲南省編輯委員会編：西双版納夕イ族社会給合調查， $1 \cdots 4$, 1983，及び9，1985

25）呂恩林：西南研究書系一西南䍗境治理，雲南教育出版社，1992

26）雲南省人口普查辨公室: 雲南省第 4 次人口普查手工或粉資料, 雲 南人民出版社，1990

27）若林敬子：中国人口超大国のゆく之，岩波新書，1994

28）菅野博貢：中国・西双版納夕イ族自治州一の嫨族移住とその社会的 影響，アジア経済，アジア経済研究所，1995.4

29）白砂剛二他：西双版納ダイ族の住居・集落に関する研究，日本建築 学会大会学術講演梗概集, pp.529·pp.542, 1995.8

30）雲南省人口普查辨公室編，雲南省第 4 次人口普查手工築秢資料，雲 南人民出版社，1990

31）国家統計局編：中国統計年鑑1994, 中国統計出版社, 1994

32）苩野博貢：中国雲南省西双版納夕イ族自治州景洪の周辺集落にみ万 流入人口の居住環境への影響と都市化のプロセスー都市・農村のマージ ナルエリアにおける民族混住についての研究 その1, 日本建築学会計 画系論文報告集，第482号， 1.996 .4 